\title{
Effect of Dietary Medium-Chain $\alpha$-Monoglycerides on the Growth Performance, Intestinal Histomorphology, Amino Acid Digestibility, and Broiler Chickens' Blood Biochemical Parameters
}

\author{
Shimaa A. Amer 1,*(D), Afaf A-Nasser ${ }^{2}$, Hanan S. Al-Khalaifah ${ }^{2}$, Dina M. M. AlSadek ${ }^{3}$, Doaa M. Abdel fattah ${ }^{4}$, \\ Elshimaa M. Roushdy ${ }^{5}$, Wafaa R. I. A. Sherief ${ }^{5}$, Mohamed F. M. Farag ${ }^{6}$, Dalia E. Altohamy ${ }^{7}$, \\ Ahmed A. A. Abdel-Wareth ${ }^{8}$ id and Abdallah E. Metwally ${ }^{1}$
}

check for

updates

Citation: Amer, S.A.; A-Nasser, A.; Al-Khalaifah, H.S.; AlSadek, D.M.M. Abdel fattah, D.M.; Roushdy, E.M.; Sherief, W.R.I.A.; Farag, M.F.M.; Altohamy, D.E.;

Abdel-Wareth, A.A.A.; et al. Effect of Dietary Medium-Chain

$\alpha$-Monoglycerides on the Growth

Performance, Intestinal

Histomorphology, Amino Acid Digestibility, and Broiler Chickens' Blood Biochemical Parameters. Animals 2021, 11, 57. https://doi.org/ 10.3390/ani11010057

Received: 10 December 2020 Accepted: 28 December 2020 Published: 30 December 2020

Publisher's Note: MDPI stays neutral with regard to jurisdictional clai$\mathrm{ms}$ in published maps and institutional affiliations.

Copyright: (C) 2020 by the authors. Licensee MDPI, Basel, Switzerland. This article is an open access article distributed under the terms and conditions of the Creative Commons Attribution (CC BY) license (https:// creativecommons.org/licenses/by/ $4.0 /)$.
1 Department of Nutrition and Clinical Nutrition, Faculty of Veterinary Medicine, Zagazig University, Zagazig 44511, Egypt; drabdalla75@yahoo.com

2 Environment and Life Sciences Research Center, Kuwait Institute for Scientific Research, P.O. Box 24885, Safat 13109, Kuwait; drhanan14@gmail.com (A.A.-N.); hkhalifa@kisr.edu.kw (H.S.A.-K.)

3 Department of Histology and Cytology, Faculty of Veterinary Medicine, Zagazig University, Zagazig 44511, Egypt; dinaaalsadek@yahoo.com

4 Department of Biochemistry, Faculty of Veterinary Medicine, Zagazig University, Zagazig 44511, Egypt; drdoaa30@yahoo.com

5 Animal Wealth Development Department, Faculty of Veterinary Medicine, Zagazig University, Zagazig 44511, Egypt; Shimaa_production@yahoo.com (E.M.R.); Wafaa.production@yahoo.com (W.R.I.A.S.)

6 Department of Clinical Pathology, Faculty of Veterinary Medicine, Zagazig University, Zagazig 44511, Egypt; farag_cell@yahoo.com

7 Department of Pharmacology, Central Laboratory, Faculty of Veterinary Medicine, Zagazig University, Zagazig 44511, Egypt; daliaaram1975@gmail.com

8 Department of Animal and Poultry Production, Faculty of Agriculture, South Valley University, Qena 83523, Egypt; A.wareth@agr.svu.edu.eg

* Correspondence: shimaa.amer@zu.edu.eg

Simple Summary: The addition of biologically active materials to animal feed is a very recent topic regarding antibiotic alternatives. This study inspected the influence of graded levels of mediumchain $\alpha$-monoglycerides, glycerol monolaurate (GML) on the growth performance, apparent ileal digestibility coefficient (AID\%) of amino acids, and intestinal histomorphology of broiler chickens. Broiler chickens $(76.82 \mathrm{~g} \pm 0.40, n=200)$ were fed on four experimental diets that were complemented with 0 ; 1; 3; or $5 \mathrm{~g} \mathrm{~kg}^{-1}$ glycerol monolaurate (GML0; GML1; GML3; and GML5). The findings suggested that glycerol monolaurate supplementation can improve the immune status and intestinal histomorphology of broiler chickens with no improving effect on the growth performance.

Abstract: This trial was conducted to assess the impact of medium-chain $\alpha$-monoglycerides, glycerol monolaurate (GML) supplementation on the growth performance, apparent ileal digestibility coefficient (AID\%) of amino acids, intestinal histomorphology, and blood biochemical parameters of broiler chickens. Three-day-old chicks $(76.82 \mathrm{~g} \pm 0.40, n=200)$ were haphazardly allocated to four experimental groups with five replicates for each (10 chicks/replicate). The treatments consisted of basal diets supplemented with four glycerol monolaurate levels; 0, 1, 3, or $5 \mathrm{~g} \mathrm{~kg}^{-1}$ (GML0, GML1, GML3, and GML5, respectively). Growth performance was determined at three periods (starter, grower, and finisher). Dietary GML had no significant effect on the growth performance parameters (body weight, weight gain, and feed conversion ratio) through all the experimental periods. GML1 diet increased the AID\% of leucine and decreased the AID \% of arginine. GML1 diet increased the duodenal and jejunal villous height and the jejunal muscle thickness. GML3 and GML5 diets increased the goblet cell count in the duodenum. GML supplementation increased the serum level of high density lipoprotein (HDL)-cholesterol. GML5 diet increased the serum levels of IgM and interleukin 10 compared to the control group. We could conclude that dietary supplementation of glycerol monolaurate can supplement broiler chicken diets up to $5 \mathrm{~g} \mathrm{~kg}^{-1}$ to enhance the immune status and intestinal histomorphology of birds with no improving effect on growth performance. 
Keywords: broiler chickens; glycerol monolaurate; growth performance; amino acid digestibility; gut health

\section{Introduction}

The replacement of antibiotics with biologically active materials in animal feed is a very recent topic. Modern feed production relies on the addition of bioactive constituents to the nutrition, which would decrease the content of antibiotics and other drugs, and have a positive effect on animal health and well-being. These components also reduce the negative effect of environmental stressors on the immune systems and production standards of an animal. Thus, in animal nutrition, the focus is on competitive exclusion, antibacterial peptides, prebiotics, probiotics, yeasts, and other additives [1-3]. These additives, which can be supplemented to chickens and piglets feed, are medium-chain fatty acids (MCFAs). Different MCFA marketable products are now accessible in the marketplace $[4,5]$.

Medium Chain Fatty Acids, 6-12 carbonic saturated fatty acids, are obviously present as medium-chain triglycerides (MCTs) in milk fats and many nutrients, particularly palm oils, coconut, and cobia seed oils [6-8]. This group involves hexanoic acid (C6:0), octanoic acid (C8:0), and decanoic acid (C10:0). Lauric acid (dodecanoic acid, C12:0) is also classified with the MCFAs [9]. Both MCTs and MCFAs have definite metabolic and nutritional effects that are important in feeding young animals, including improved digestion, passive absorption, and obligatory oxidation [10]. Hydrolysis of MCTs occurs quickly compared to long-chain triglycerides (LCTs) without the need for emulsion with bile because of its high solubility in water.

MCTs are initially digested in the stomach by lingual and gastric lipases producing substantial MCFAs and monoglycerides, before entering the small intestine. In the duodenum, pancreatic lipases are released; the absorption of MCFAs becomes available [11]. Most MCFAs are absorbed in their free form by passive diffusion, but absorption as acyl ester has also been established [12]. MCFAs are not re-esterified within the intestinal cells but are diffused into the portal blood due to a low fatty acid-binding protein affinity, linked to albumin, and transported directly to the liver [13-15]. A minor proportion of MCFAs are ingested by chylomicrons $[9,16]$. Moreover, MCFAs have an antibacterial activity like short-chain fatty acids [17].

In poultry production, MCFA and related glycerides have apparent effects on production performance and egg quality $[18,19]$. Medium-chain $\alpha$-monoglycerides are auspicious feed additives for the broilers industry. Glycerol monolaurate (GML) made from lauric acid and glycerol that lacks of toxicity, exhibits growth promoter capacity and potent antimicrobial activity [20]. They suggested that MGL could be used as an alternative antimicrobial in poultry farming. The current study aimed to evaluate the impact of dietary supplementation of glycerol monolaurate on the growth performance, amino acid ileal digestibility, blood biochemical parameters, and intestinal histology of broiler chickens.

\section{Materials and Methods}

\subsection{Birds, Experimental Design, and Diets}

The ethics of the experimental protocol were approved by the Institutional Animal Care and Use Committee of Zagazig University, Egypt (ZUIACUC-2019). All animal experiments were performed following the recommendations described in "The Guide for the Care and Use of Laboratory Animals in scientific investigations."

Two hundred one-day-old chicks (Ross 308 broiler) were obtained from a marketable chick producer. Before starting the experiment, chicks were submitted to a 3-day adaptation period to reach an initial body weight of $76.82 \mathrm{~g} \pm 0.40$. They were haphazardly allocated to four experimental groups with five replicates (10 chicks/replicate). Birds were fed on basal diets supplemented with four levels of glycerol monolaurate: $0,1,3$, or $5 \mathrm{~g} \mathrm{~kg}^{-1}$ (GML0, GML1, GML3, and GML5, respectively) (glycerol monolaurate, FRA ${ }^{\circledR}$ 
C12, Framelco, Ruisvoorn 5, 4941 SB, Raamsdonksveer, Holanda). The experiment lasted for 35 days, with continuous lighting and adequate ventilation. Freshwater and feed were offered for ad libitum consumption throughout the investigation. The routine health and vaccination practices were implemented strictly according to the recommendations. The chicks were checked daily to ensure there were no health problems. The formula and chemical composition of the basal diet are shown in (Table 1). An approximate chemical analysis of the feed used and experimental diets was performed according to the standard procedures for the Ross 308 broiler feed specification, AVIAGEN [21].

Table 1. The proximate chemical composition of the basal diet as fed basis (\%).

\begin{tabular}{|c|c|c|c|c|}
\hline Ingredients & Unit & Starter & Grower & Finisher \\
\hline Corn $7.5 \% \mathrm{cp}$ & $\%$ & 53.02 & 58 & 62.50 \\
\hline Soybean meal $47 \%$ cp & $\%$ & 37 & 32 & 26.00 \\
\hline Corn gluten meal $60 \% \mathrm{cp}$ & $\%$ & 3.5 & 3.2 & 4.50 \\
\hline Oil (soya) & $\%$ & 2 & 3 & 3.50 \\
\hline Dicalcium phosphate $18 \%$ & $\%$ & 2 & 1.7 & 1.45 \\
\hline Calcium carbonate & $\%$ & 0.7 & 0.5 & 0.50 \\
\hline Sodium bicarbonate & $\%$ & 0.35 & 0.33 & 0.32 \\
\hline Dl methionine $99 \%$ & $\%$ & 0.36 & 0.28 & 0.30 \\
\hline Broiler premix * & $\%$ & 0.3 & 0.3 & 0.30 \\
\hline L-LYSINE HCL 98\% & $\%$ & 0.3 & 0.3 & 0.28 \\
\hline Salt & $\%$ & 0.15 & 0.11 & 0.13 \\
\hline Antimycotoxin & $\%$ & 0.1 & 0.1 & 0.10 \\
\hline Choline 60 veg & $\%$ & 0.07 & 0.07 & 0.07 \\
\hline L-THREONINE 98.5\% & $\%$ & 0.1 & 0.1 & 0.06 \\
\hline Enzyme Phytase & $\%$ & 0.005 & 0.005 & 0.005 \\
\hline \multicolumn{5}{|l|}{ Chemical analysis ** } \\
\hline Moisture & $\%$ & 11.27 & 11.23 & 11.17 \\
\hline ME poultry. (kcal/kg) & $\mathrm{Kcal} / \mathrm{kg}$ & 3007.24 & 3103.42 & 3202.13 \\
\hline Crude protein analysis & $\%$ & 23.70 & 21.55 & 20.13 \\
\hline Crude protein $\%$ & $\%$ & 24.22 & 21.90 & 20.42 \\
\hline Lysine $\mathrm{g}$ & $\mathrm{g} / \mathrm{kg}$ & 14.56 & 13.20 & 11.59 \\
\hline Methionine $\mathrm{g}$ & $\mathrm{g} / \mathrm{kg}$ & 7.25 & 6.18 & 6.14 \\
\hline Methionine + cystine $g$ & $\mathrm{~g} / \mathrm{kg}$ & 10.90 & 9.58 & 9.40 \\
\hline Threonine $\mathrm{g}$ & $\mathrm{g} / \mathrm{kg}$ & 9.99 & 9.13 & 8.12 \\
\hline Tryptophan g & $\mathrm{g} / \mathrm{kg}$ & 2.79 & 2.49 & 2.19 \\
\hline Arginine g & $\mathrm{g} / \mathrm{kg}$ & 15.32 & 13.72 & 12.15 \\
\hline Valine $\mathrm{g}$ & $\mathrm{g} / \mathrm{kg}$ & 11.32 & 10.27 & 9.58 \\
\hline Crude Fat \% & $\%$ & 4.98 & 6.04 & 6.68 \\
\hline C18:2 linoleic ac. \% & $\%$ & 2.32 & 2.90 & 3.22 \\
\hline Ash \% & $\%$ & 6.35 & 5.53 & 5.01 \\
\hline Calcium g & $\mathrm{g} / \mathrm{kg}$ & 9.47 & 8.95 & 8.21 \\
\hline Av. Phosphorus & $\mathrm{g} / \mathrm{kg}$ & 4.97 & 4.47 & 4.03 \\
\hline $\mathrm{Clg}$ & $\mathrm{g} / \mathrm{kg}$ & 2.63 & 2.32 & 2.35 \\
\hline Sodium g & $\mathrm{g} / \mathrm{kg}$ & 1.85 & 1.62 & 1.67 \\
\hline Potassium $g$ & $\mathrm{~g} / \mathrm{kg}$ & 8.84 & 8.05 & 7.06 \\
\hline Manganese mg & $\mathrm{mg} / \mathrm{kg}$ & 102.81 & 99.69 & 96.34 \\
\hline DEB & $\mathrm{meq} / \mathrm{kg}$ & 247.64 & 223.99 & 197.65 \\
\hline Crude fiber & $\%$ & 3.426 & 3.23 & 2.98 \\
\hline A.D.F. & $\%$ & 4.69 & 4.43 & 4.10 \\
\hline N.D.F. & $\%$ & 10.33 & 10.22 & 10.01 \\
\hline Starch \% & $\%$ & 35.09 & 38.27 & 41.20 \\
\hline Total Sugar \% & $\%$ & 3.88 & 3.54 & 3.13 \\
\hline Vit A & kU.I & 9.55 & 9.55 & 9.55 \\
\hline Vit D3 & kU.I & 4.66 & 2.66 & 2.66 \\
\hline
\end{tabular}


Table 1. Cont.

\begin{tabular}{ccccc}
\hline Ingredients & Unit & Starter & Grower & Finisher \\
\hline Vit E & $\mathrm{mg} / \mathrm{kg}$ & 19.14 & 19.14 & 19.14 \\
Choline chloride & $\mathrm{mg} / \mathrm{kg}$ & 1732.12 & 1625.40 & 1534.00 \\
Choline chloride equivalent & $\mathrm{mg} / \mathrm{kg}$ & 420 & 420 & 420.00 \\
\hline
\end{tabular}

* Premix per kg of diet: vitamin A, $1500 \mathrm{IU}$; vitamin D3, $200 \mathrm{IU}$; vitamin E, $10 \mathrm{mg}$; vitamin K3, 0.5 mg; thiamine, $1.8 \mathrm{mg}$; riboflavin, $3.6 \mathrm{mg}$; pantothenic acid, $10 \mathrm{mg}$; folicacid, $0.55 \mathrm{mg}$; pyridoxine, $3.5 \mathrm{mg}$; niacin, $35 \mathrm{mg}$; cobalamin, $0.01 \mathrm{mg}$; biotin, $0.15 \mathrm{mg}$; Fe, $80 \mathrm{mg} ; \mathrm{Cu}, 8 \mathrm{mg}$; $\mathrm{Mn}, 60 \mathrm{mg} ; \mathrm{Zn}, 40 \mathrm{mg}$; I, 0.35 mg; Se, $0.15 \mathrm{mg}$. ** According to (Aviagen, 2014). Cp: crude protein, ME: metabolizable energy, DEB: dietary electrolyte balance. A.D.F.: Acid detergent fiber, N.D.F.: Neutral detergent fiber.

\subsection{Growth Performance}

The average initial body weight was obtained on the 4th day of age. Then the body weight was recorded at $10,23,35$ days.

The body weight gain $(\mathrm{g} / \mathrm{bird})=\mathrm{W} 2-\mathrm{W} 1$, where $\mathrm{W} 2$ is the final body weight at the intended period, and W1 is the initial body weight in the same period.

Feed intake $(\mathrm{g} / \mathrm{bird})=$ feed offered weight - residues left $/$ birds No.

The feed conversion ratio (FCR) was estimated weekly: FCR = the amount of feed consumed (g)/Bodyweight gain (g).

The relative growth rate (RGR) was calculated using the equation described by [22].

$\mathrm{RGR}=\mathrm{W} 2-\mathrm{W} 1 / \frac{1}{2}(\mathrm{~W} 1+\mathrm{W} 2) \times 100 . \mathrm{W} 1=$ the initial live weight $(\mathrm{g}), \mathrm{W} 2=$ the live weight at the end of the considered period $(\mathrm{g})$.

Protein efficiency ratio (PER) was determined according to [23].

PER = Live weight gain (g)/Protein intake (g).

\subsection{Amino Acids Ileal Digestibility}

Titanium dioxide, an indigestible indicator substance, was used to determine the amino acid ileal digestibility described by [24]. The amino acid concentration in the diet and ileal digesta samples were measured according to Li et al. $[25,26]$. Tryptophan was measured separately, according to Ravindran and Bryden [27]. Titanium dioxide was valued following the procedures of Fenton and Fenton [28]. The apparent ileal digestibility coefficient (AID\%) of amino acids was estimated by the following equation:

$\operatorname{AID}(\%)=100-\left[\left(\mathrm{Ti}_{(\text {diet })} \times \mathrm{AA}_{(\text {ileum })}\right) /\left(\mathrm{TI}_{(\text {ileum })} \times \mathrm{AA}_{(\text {diet })}\right) \times 100\right]$.

$\mathrm{Ti}$ (diet): the titanium dioxide concentration in the diet.

Ti (ileal): the titanium dioxide concentration in ileal digesta.

AA (ileal): the concentration of the test AA in the ileal digesta sample.

AA (diet): the concentration of the test AA in the diet.

\subsection{Sample Collection and Laboratory Analyses}

At the end of the feeding period ( 35 days), blood samples were randomly collected from five birds per treatment after slaughter into rubber stoppers sterilized tubes. Samples were left to coagulate at $4{ }^{\circ} \mathrm{C}$ and centrifuged at $3500 \mathrm{rpm}$ for $15 \mathrm{~min}$ to obtain serum, and the serum samples were retained in Eppendorf tubes at $-20^{\circ} \mathrm{C}$ until they were analyzed. Samples from different parts of the small intestine (duodenum, jejunum, ileum) were taken for histological examination.

An enzymatic method was used to determine total serum cholesterol with a single aqueous reagent using colorimetric diagnostic kits of spectrum-bioscience (Egyptian Company for Biotechnology, Cairo, Egypt) following the methods of Allain et al. [29]. A peroxidase-coupled method was used for the colorimetric determination of serum triglycerides following the practices of McGowan et al. [30]. The enzymatic colorimetric method was used to determine the serum level of high density lipoprotein (HDL)-C following the procedures of Vassault et al. [31]. The Iranian formula of low density lipoprotein (LDL)-C = total cholesterol (TC) $/ 1.19$ + triglycerides (TG) $/ 1.9-\mathrm{HDL} / 1.1-38$ was used for LDL-C calculation. Chicken ELISA kits of MyBioSource Co. of CAT.NO. MBS012469, 
MBS701683, and of ABCAM Co. of CAT. NO. AB157691 were used to determine the serum levels of alkaline phosphatase, interleukin 10, and IgM, respectively. Meanwhile, a sandwich enzyme-linked immunosorbent assay (ELISA) kit manufactured by Life Span Biosciences, Inc. of CAT.NO.LS-F9287 was used for determining serum complement 3 levels by following the manufacturer's instructions.

\subsection{Histological Examination of the Small Intestine}

The whole small intestinal tract was sampled for histomorphological examination. Two-cm tissue samples were taken from the duodenum, jejunum, and ileum, according to the method of Giannenas et al. [32]. The tissue samples were briefly preserved in $10 \%$ neutral buffered formaldehyde (NBF) for $72 \mathrm{~h}$, then processed for dehydration and clearing, and embedded in wax. Histological study was performed on $5-\mu \mathrm{m}$ thick transverse sections (cut by a microtome), fixed on slides, and stained with hematoxylin and eosin [33] and acidic mucus containing goblet cells were identified using periodic acid-Schiff (PAS) staining. The mucosal and muscular layer of the duodenum, jejunum and ileum were examined using a digital camera (Canon) connected to a light microscope (Zeiss). Camera microscope AmScope ${ }^{\circledR}$ software (AmScope digital cameraattached Ceti England microscope) was used for morphometric analysis as follows: villus height was measured from the tip (with a lamina propria) of the villus to the base (villus-crypt junction), crypt depth was measured from the villus-crypt intersection to the distal limit of the crypt, and the thickness of the tunica muscularis was defined as the distance between the lamina muscularis mucosae internally and the tunica serosa externally. ImageJ was used to calculate the number of goblet cells in PAS stained sections per unit of epithelial area $\left(\mathrm{mm}^{2}\right)$ and individual goblet cell areas $\left(\mu \mathrm{m}^{2}\right)$.

\subsection{Statistical Analysis}

Data were analyzed with a one-way analysis of variance (ANOVA) using the general linear model procedure in SPSS sofware (SPSS Inc., Chicago, Illinois, USA) after Shapiro-Wilk's test was used to verify the normality and Levene's test was used to verify homogeneity of variance components between experimental treatments. Tukey's test was used to compare the differences between the means at $5 \%$ probability. Variation in the data was expressed as pooled standard error of mean (SEM), and the significance level was set at $p<0.05$.

\section{Results}

\subsection{Growth Performance}

Glycerol monolaurate supplementation had no significant effect on BW, BWG, feed intake (FI), FCR, PER, and RGR all over the experimental periods compared to the control group $(p>0.05)$ (Table 2$)$.

Table 2. The effect of glycerol monolaurate supplementation on the growth performance of broiler chickens.

\begin{tabular}{ccccccc}
\hline Parameters & GML0 & GML1 & GML3 & GML5 & SEM & $p$ Value \\
\hline $\begin{array}{c}\text { Initial weight (g) } \\
\text { Starter period }\end{array}$ & 77.00 & 77.41 & 75.45 & 77.62 & 0.40 & 0.67 \\
BW(g) & 222.66 & 219.70 & 220.87 & 223.04 & 2.02 & 0.96 \\
BWG(g) & 145.66 & 142.29 & 145.41 & 145.41 & 2.39 & 0.95 \\
FI (g) & 187.41 & 189.20 & 188.45 & 187.33 & 2.26 & 0.98 \\
FCR & 1.28 & 1.33 & 1.30 & 1.29 & 0.01 & 0.84 \\
\hline Grower period & & & & & & \\
BW(g) & 876.91 & 858.00 & 851.29 & 856.50 & 14.80 & 0.92 \\
BWG(g) & 654.25 & 638.29 & 630.41 & 633.45 & 10.66 & 0.92 \\
FI (g) & 994.08 & 923.54 & 957.37 & 955.37 & 9.52 & 0.51 \\
FCR & 1.527 & 1.445 & 1.519 & 1.512 & 0.01 & 0.55 \\
\hline
\end{tabular}


Table 2. Cont.

\begin{tabular}{ccccccc}
\hline Parameters & GML0 & GML1 & GML3 & GML5 & SEM & $p$ Value \\
\hline Finisher period & & & & & & \\
BW(g) & 1932.91 & 1851.00 & 1879.45 & 1909.37 & 31.37 & 0.93 \\
BWG(g) & 1056.00 & 993.00 & 1028.16 & 1052.87 & 29.23 & 0.92 \\
FI(g) & 2074.25 & 1978.50 & 2030.91 & 2124.00 & 22.27 & 0.81 \\
FCR & 1.075 & 1.073 & 1.08 & 1.12 & 0.017 & 0.93 \\
\hline Overall performance & & & & & & \\
BW(g) & 1932.91 & 1851.00 & 1879.45 & 1909.37 & 31.37 & 0.93 \\
BWG(g) & 1855.91 & 1773.58 & 1804.00 & 1831.75 & 29.001 & 0.93 \\
FI (g) & 3255.75 & 3091.25 & 3176.75 & 3266.70 & 42.87 & 0.78 \\
FCR & 1.75 & 1.75 & 1.76 & 1.79 & 0.025 & 0.98 \\
PER & 2.74 & 2.75 & 2.73 & 2.72 & 0.03 & 0.99 \\
RGR & 184.61 & 183.79 & 184.45 & 184.32 & 0.19 & 0.82 \\
\hline
\end{tabular}

Means within the same row carrying different superscripts are significantly different at $(p<0.05)$. BW: body weight, BWG: body weight gain, FI: feed intake, FCR: feed conversion ratio, PER: protein efficiency ratio, RGR: relative growth rate. GML0, GML1, GML3, and GML5: basal diets supplemented with $0,0.1$ or 0.3 or $0.5 \%$ glycerol monolaurate, respectively.

\subsection{Apparent Ileal Digestibility Coefficient (AID\%) of Amino Acids}

As shown in Table 3, The AID\% of leucine was increased in the GML1 diet and decreased by increasing glycerol monolaurate level $(p=0.003)$. The AID $\%$ of arginine was significantly reduced in the GML1 diet $(p<0.05)$. The AID\% of threonine, lysine, methionine, tryptophan, valine, and isoleucine were not significantly different between the control and other supplemented groups $(p>0.05)$.

Table 3. The effect of glycerol monolaurate supplementation on the apparent ileal digestibility coefficient (AID\%) of amino acids.

\begin{tabular}{ccccccc}
\hline Parameters & GML0 & GML1 & GML3 & GML5 & SEM & $p$ Value \\
\hline Lysine & 89.12 & 88.82 & 88.95 & 88.87 & 0.08 & 0.16 \\
Methionine & 87.54 & 87.7 & 87.21 & 87.46 & 0.06 & 0.12 \\
Threonine & 85.71 & 85.46 & 85.22 & 85.09 & 0.12 & 0.07 \\
Tryptophan & $87.67^{\mathrm{a}}$ & 77.63 & 87.44 & 86.99 & 0.18 & 0.47 \\
Arginine & $90.45^{\mathrm{a}}$ & $89.95^{\mathrm{b}}$ & $90.20^{\mathrm{ab}}$ & $90.37^{\mathrm{ab}}$ & 0.03 & 0.04 \\
Valine & $86.01^{\mathrm{b}}$ & 85.59 & 85.69 & 85.54 & 0.05 & 0.07 \\
Leucine & $90.68^{\mathrm{b}}$ & $91.01^{\mathrm{a}}$ & $90.42^{\mathrm{bc}}$ & $90.31^{\mathrm{c}}$ & 0.05 & 0.003 \\
Isoleucine & 86.10 & 86.34 & 85.98 & 86.24 & 0.05 & 0.22 \\
\hline
\end{tabular}

$a, b, c$ Means within the same row carrying different superscripts are significantly different at $(p<0.05)$. TC: total cholesterol, TG: triglycerides, HDL: high density lipoprotein, LDL: low density lipoprotein. GML0, GML1, GML3, and GML5: basal diets supplemented with $0,0.1$ or 0.3 or $0.5 \%$ glycerol monolaurate, respectively.

\subsection{Morphometric Measures of the Small Intestine}

The morphometric measurements of the different parts of the small intestine of birds fed on the experimental diets are shown in Table 4 and Figures 1 and 2. The duodenal villous height was increased in the GML1 and GML3 groups and decreased in the GML5 group $(p=0.00)$. The goblet cell count (GCC) in the duodenum was raised in the GML3 and GML5 groups compared to the GML1 group $(p=0.009)$, but it was not significantly different from the control group. The jejunal muscle thickness and villous height were increased in the GML1 group compared to the control group $(p<0.05)$. The jejunal crypt depth was decreased in the GML3 and GML5 groups $(p=0.00)$. The GCC in the jejunum was not significantly different in all glycerol monolaurate-supplemented groups compared to the control group. The goblet cell count in the ileum was increased in the GML3 group compared to the control group $(p=0.003)$. The mucosal thickness, villous height, and crypt depth of the ileum were not significantly different among the groups $(p>0.05)$. 
Table 4. The effect of glycerol monolaurate supplementation on the morphometric measures $(\mu \mathrm{m})$ of the small intestine of broiler chickens.

\begin{tabular}{|c|c|c|c|c|c|c|}
\hline Parameters & GML0 & GML1 & GML3 & GML5 & SEM & $p$ Value \\
\hline \multicolumn{7}{|l|}{ Duodenum } \\
\hline Muscle thickness & 121.80 & 125.61 & 114.78 & 114.01 & 9.30 & 0.78 \\
\hline Crypt depth & 247.98 & 243.59 & 205.93 & 186.05 & 13.78 & 0.19 \\
\hline Villus height & $582.39^{c}$ & $1111.66^{a}$ & $796.03^{b}$ & $716.12 \mathrm{bc}$ & 56.01 & 0.00 \\
\hline Goblet cell count & $25^{\mathrm{ab}}$ & $22.66^{\mathrm{b}}$ & $32.33^{\mathrm{a}}$ & $31^{\mathrm{a}}$ & 1.32 & 0.009 \\
\hline \multicolumn{7}{|l|}{ Jejunum } \\
\hline Muscle thickness & $117.06^{b}$ & $183.72^{\mathrm{a}}$ & $142.94^{\mathrm{ab}}$ & $106.18^{b}$ & 26.90 & 0.01 \\
\hline Crypt depth & $252.83^{a}$ & $223.38^{a}$ & $128.83^{b}$ & $158.91^{b}$ & 11.60 & 0.00 \\
\hline Villus height & $672.81^{b}$ & $1067.44^{\mathrm{a}}$ & $770.84^{b}$ & $715.82^{b}$ & 45.57 & 0.00 \\
\hline Goblet cell count & 40.66 & 35 & 44.66 & 39.33 & 1.58 & 0.05 \\
\hline \multicolumn{7}{|l|}{ Ileum } \\
\hline Muscle thickness & 219.02 & 246.56 & 175.79 & 235.28 & 17.93 & 0.55 \\
\hline Crypt depth & 117.06 & 124.81 & 110.02 & 112.75 & 7.59 & 0.45 \\
\hline Villus height & 323.87 & 323.35 & 363.15 & 371.23 & 29.81 & 0.18 \\
\hline Goblet cell count & $70^{a b}$ & $56.33^{b}$ & $80^{a}$ & $55.66^{b}$ & $2.57^{b}$ & 0.003 \\
\hline
\end{tabular}

a,b,c Means within the same row carrying different superscripts are significantly different at $(p<0.05)$. GML0, GML1, GML3, and GML5: basal diets supplemented with 0, 0.1 or 0.3 or $0.5 \%$ glycerol monolaurate, respectively.
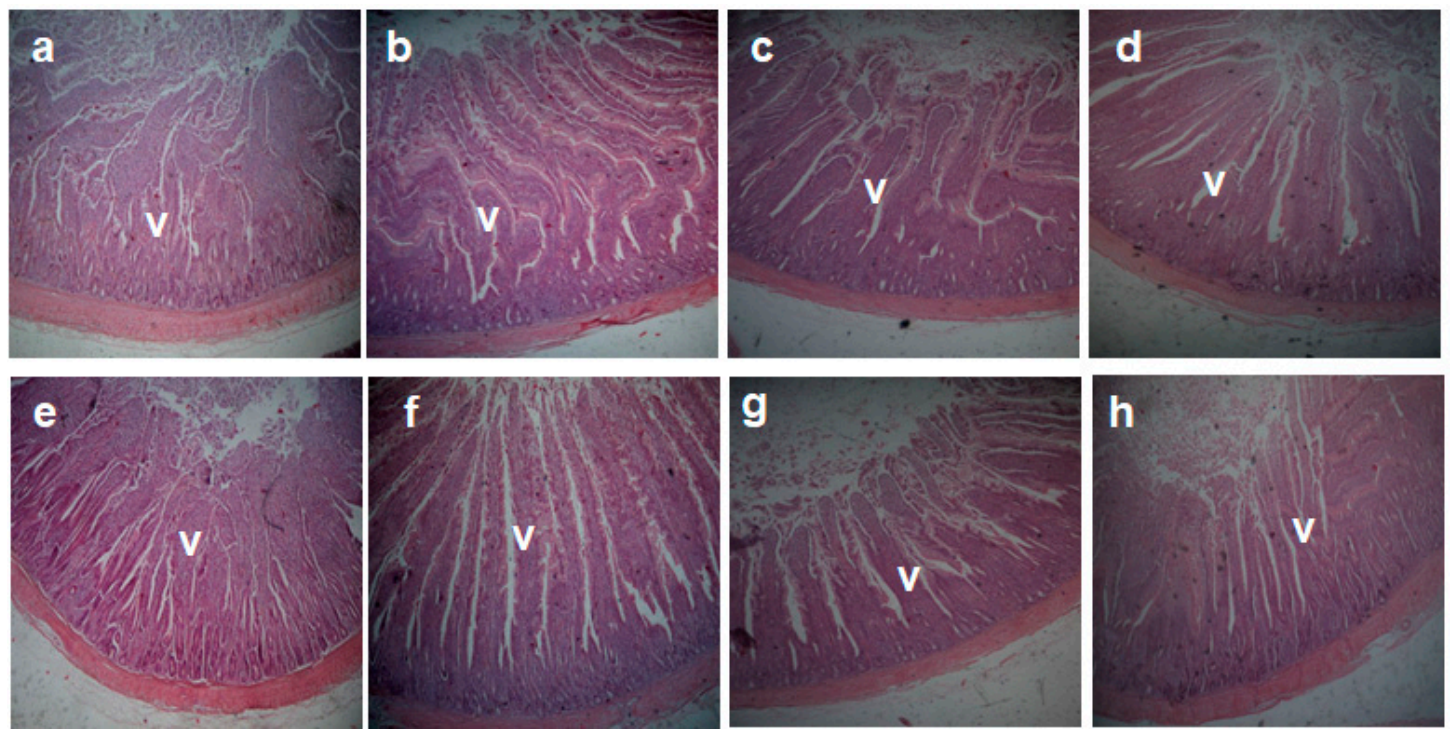

Figure 1. A representative photomicrograph of $40 \times$ magnification H\&E stained small intestine sections of the broiler chickens. (a-d) Duodenal sections from control group, GML1, GML3, and GML5 groups, respectively, showing increase in villus (V) length in GML1, GML3 groups and decrease in the GML5 group. (e-h) Jejunal sections from the control group, GML1, GML3, and GML5 groups, respectively, showing increase in villus (V) length in the GML1 group compared to the control group.

\subsection{Lipid Profile and the Level of Alkaline Phosphatase "ALP"}

Supplementation of GML increased the serum level of HDL-cholesterol compared to GML0 $(p=0.01)$. GML5 diet increased the serum level of triglycerides in comparison with GML1 and GML3 diets ( $p=0.009)$, but its level was not significantly different in all GML-supplemented groups compared to GML0 $(p>0.05)$. Supplementation of GML had no significant effect on the serum levels of ALP, total cholesterol, and LDL-cholesterol $(p>0.05)$ (Table 5). 

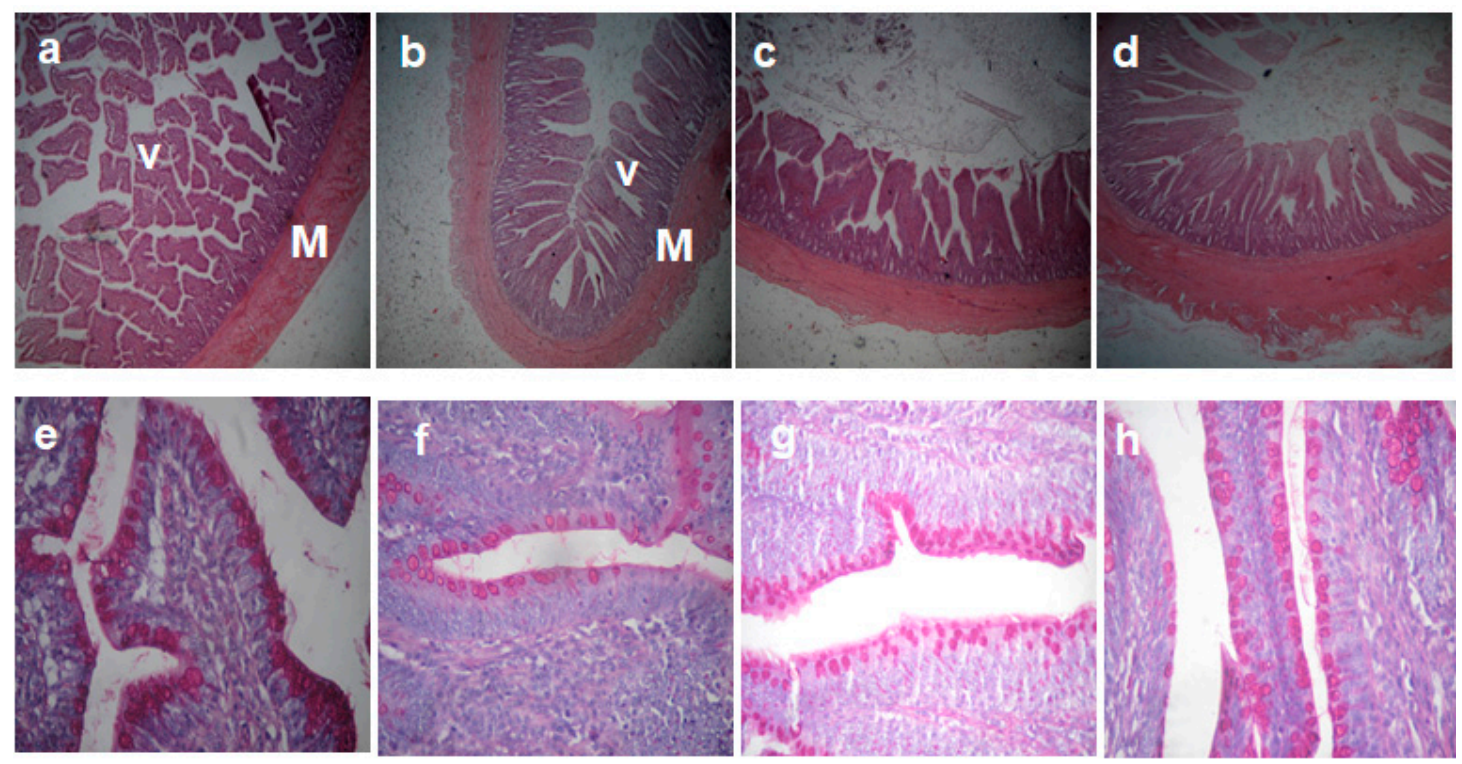

Figure 2. A representative photomicrograph of $40 \times$ magnification H\&E stained small intestine sections of the broiler chickens. (a-d) Ileal sections from the control group, GML1, GML3, and GML5 groups, respectively, showing no significant difference in the villous height (V), crypt depth and muscle thickness (M) between different groups. (e-h) Goblet cells (arrow) in the ileum from the control group, GML1, GML3, and GML5 groups, respectively, increased in the GML3 group compared to the control group.

Table 5. The effect of glycerol monolaurate supplementation on the lipid profile and the level of alkaline phosphatase (ALP) of broiler chickens.

\begin{tabular}{ccccccc}
\hline Parameters & GML0 & GML1 & GML3 & GML5 & SEM & $p$ Value \\
\hline TC $(\mathrm{mg} / \mathrm{dL})$ & 218.36 & 223.80 & 229.53 & 229.58 & 2.39 & 0.43 \\
TG $(\mathrm{mg} / \mathrm{dL})$ & $143.08^{\mathrm{ab}}$ & $125.92^{\mathrm{b}}$ & $132.01^{\mathrm{b}}$ & $195.6^{\mathrm{a}}$ & 5.63 & 0.009 \\
HDL $(\mathrm{mg} / \mathrm{dL})$ & $34.66^{\mathrm{b}}$ & $51.23^{\mathrm{a}}$ & $72.05^{\mathrm{a}}$ & $72.28^{\mathrm{a}}$ & 3.34 & 0.011 \\
$\mathrm{LDL}(\mathrm{mg} / \mathrm{dL})$ & 161.07 & 174.57 & 192.32 & 149.70 & 8.70 & 0.16 \\
ALP $(\mathrm{U} / \mathrm{L})$ & 39.49 & 39.34 & 41.17 & 51.95 & 6.35 & 0.32 \\
\hline
\end{tabular}

a,b Means within the same row carrying different superscripts are significantly different at $(p<0.05)$. TC: total cholesterol, TG: triglycerides, HDL: high density lipoprotein, LDL: Low density lipoprotein. GML0, GML1, GML3, and GML5: basal diets supplemented with $0,0.1$ or 0.3 or $0.5 \%$ glycerol monolaurate, respectively.

\subsection{Immune Status}

The GML5 diet increased the serum levels of IgM and interleukin 10 compared to the control group $(p<0.05)$. Supplementation of GML had no significant influence $(p>0.05)$ on the serum level of complement 3 (Table 6).

Table 6. The effect of of glycerol monolaurate supplementation on the immune status of broiler chickens.

\begin{tabular}{ccccccc}
\hline Parameters & GML0 & GML1 & GML3 & GML5 & SEM & $p$ Value \\
\hline IgM $(\mathrm{mg} / \mathrm{dL})$ & $42.65^{\mathrm{b}}$ & $72.13^{\mathrm{b}}$ & $75.01^{\mathrm{b}}$ & $132.01^{\mathrm{a}}$ & 10.89 & 0.001 \\
C3 $(\mathrm{mg} / \mathrm{dL})$ & 67.00 & $64.87^{\mathrm{b}}$ & 89.27 & 80.24 & 5.55 & 0.28 \\
IL10 $(\mathrm{pg} / \mathrm{mL})$ & $0.12^{\mathrm{b}}$ & $0.17^{\mathrm{b}}$ & $0.25^{\mathrm{ab}}$ & $0.30^{\mathrm{a}}$ & 0.01 & 0.004 \\
\hline
\end{tabular}

$\mathrm{a}, \mathrm{b}$ Means within the same row carrying different superscripts are significantly different at $(p<0.05)$. GML0, GML1, GML3, and GML5: basal diets supplemented with $0,0.1$ or 0.3 or $0.5 \%$ glycerol monolaurate, respectively. 


\section{Discussion}

With the recent ban and restrictions of using antibiotics as growth promoters, many feed supplements are widely added in poultry feeds as alternative growth promoters, such as prebiotics, phytobiotics, probiotics, organic acids, and enzymes [24,34-38]. Recently, MCFAs have received more consideration because of their potential antimicrobial effects. Growth performance can be improved by $4 \%$ and $12 \%$ for increased BW and FCR, respectively, due to improved gut health and environment by MCFAs [39]. MCFAs are usually documented as safe (GRAS) by the Food and Drug Administration [40]. Dietary MCFAs have been reported to enhance the growth performance and intestinal histomorphology and decrease the invasion of the intestinal pathogen and mortality in broiler chickens [41,42] and Japanese quail [43]. Many studies have shown that the effectiveness of MCFAs in stimulating bird growth will produce a final result to improve the gastrointestinal ecology, with the ensuing intestinal environment, intestinal mucosal integrity, the digestive and immune status of the gut, and the broiler chickens health [44-46]. Other studies have shown no improvement in broiler chickens' performance when the birds fed on MCFAs-complemented diets are compared to control birds and antibiotics-fed birds $[47,48]$.

The current results show that dietary supplementation of graded levels of glycerol monolaurate had no improving effect on the bird's growth throughout the experimental period, which may be due to the insignificant effect of GML supplementation on the AID\% of amino acids except for the increased AID\% of leucine in the GML1 group and the decreased AID\% of arginine in the GML1 group. Moreover, GML supplementation did not affect the FI and feed utilization, where feed intake is an essential feature guiding the broiler's growth rate [49]. Similar results were informed in quail chicks fed MCFAs supplemented diets by levels of 1,2 , and $4 \mathrm{~g} / \mathrm{kg}$ at different experiment stages [43]. Hejdysz et al. [50] showed no significant improvement of the bodyweight gains by mediumchain fatty acids supplementation in chickens. Liu et al. [51] observed no significant difference in growth performance during the starter and grower stage, but during the finisher period, the average daily feed intake and BW were increased by supplementation of 300,450 , and $600 \mathrm{mg} / \mathrm{kg}$ medium-chain $\alpha$-monoglycerides. They attributed the improved body weight to the increased feed intake caused by the supplementation. Lipiński et al. [52] reported enhanced turkey growth by dietary supplementation with MCFA glycerides and a herbal additive. Devi and Kim [53] showed a significant elevation in the average daily gain and feed efficiency ratio of pigs caused by MCFAs supplementation alone or with probiotics. Mabayo et al. [54] informed that MCTs-supplementation of the chick diet improved body protein utilization and weight gain while controlling fat deposition compared to the LCTs-supplemented diet. Allee et al. [55] reported no significant changes in WG, FI, and feed efficiency of pigs fed $10 \%$ MCTs supplemented diet compared to those fed on diets complemented with tallow, pig fat, or corn oil at the same level. Furthermore, the results of Baltic et al. [56] showed that broiler diets supplemented with MCFAs affected the broiler performance positively. Decuypere and Dierick [57] attributed the improved growth performance to the antibacterial effects of the MCFAs, especially against pathogenic bacteria. Others have related the performance effects to the effect of MCFAs on the epithelial function in the upper small intestine, either directly or indirectly by increasing the absorptive surface, increasing uptake and producing a higher nutrient utilization for growth. Intestinal cells can immediately utilize MCFAs to produce energy and thus support the intestinal tissue integrity in post-weaning piglets [15]. Rats fed on MCTs-supplemented diets showed improved intestinal morphology indicated by mucosa augmentation, longer intestinal villi, shorter crypts, increased phospholipid/protein ratio in the lipids' jejunal mucosal, and increased membrane-bound enzymes activity [58].

The small intestine has a pivotal role in nutrient digestion and absorption in broiler chickens. Improving intestinal development increases the utilization of nutrients by the broiler, leading to improved growth performance [41]. Although the current study results showed an optimistic effect of glycerol monolaurate supplementation on the morphometric measures (muscle thickness and villous height $(\mathrm{VH})$ ) of the different parts of the intestine, 
especially the GML1 group, this improvement was not reflected on the birds' growth or nutrient digestibility. Several studies showed that dietary supplementation of MCFA increased the $\mathrm{VH}$, villous width (VW), and the absorptive area of the small intestine of broiler chicks at 14 days old [59-63]. Leeson et al. [64] and Panda et al. [65] reported improved duodenal VH and crypt depth (CD) by MCFAs supplementation in broilers' diet that could be helpful for intestinal development in young birds. High duodenal and ileal villus heights by MCFAs supplementation in birds' diets were also documented by $[56,66]$. Increasing villus length can increase enzyme production and improve digestion by increasing effective absorbance and enhancing nutrient absorption [67]. MCFA and related glycerides can be directly taken up by enterocytes to produce energy in the small intestine and improve gut growth and integrity in farm animals [68]. Liu et al. [51] reported an increase in the jejunal villus length and $\mathrm{VH}$ : CD ratio in the duodenum and ileum by dietary GML. Zhao, et al. [69] reported improved Intestinal morphology by GML supplementation indicated by increased $\mathrm{VH}$ and $\mathrm{VH}$ : CD ratio. Liu, et al. [70] reported improved growth, muscle amino acids, and intestinal morphology in broilers by GML supplementation (300, 450, and $600 \mathrm{mg} / \mathrm{kg}$ ) mostly by influencing the gut microbiota function and community. Pan and $\mathrm{Yu}$ [71] demonstrated that short chain fatty acids (SCFAs) can act as energy source for intestinal epithelial cells and enhance the growth and proliferation of intestinal cells. Thus, one possible clarification for improving gut morphology by GML may be derived from the high SCFAs levels in the gastrointestinal tract. Furthermore, increased SCFAs may improve the intestinal health and may assist the host in maintaining mucosal barrier integrity [70,72]. Mo, et al. [73] showed that dietary GML improved the intestinal integrity and gut barrier function in mice.

Concerning the effect of glycerol monolaurate supplementation on the lipid profile of broiler chickens, GML supplementation increased the serum level of HDL-cholesterol and the GML5 group displayed higher serum levels of triglycerides than GML1 and GML3 groups. These results agree with the results of Liu et al. [51], who demonstrated increased serum HDL-cholesterol in birds fed with 300 and $450 \mathrm{mg} / \mathrm{kg}$ medium-chain a-monoglycerides. Modification of the serum lipid profile showed that dietary medium chain glycerides could efficiently enhance the fat metabolism in broiler chickens. MCFA and the related glycerides were associated with increased carriage of extra cholesterol, leading to lower serum cholesterol levels [74,75]. MCFA supplementation in broiler food reduced LDL cholesterol levels and increased HDL-C content [76]. Baltić et al. [56] showed increased serum triglyceride level and no significant effect on HDL-C level in broilers with MCFAs supplementation. The increased triglyceride level caused by MCFAs supplementation observed in this study is in line with the results of [77]. However, the MCFAs' effects on cholesterol and triglyceride appeared to be conflicting, as cholesterol and triglyceride secretion is controlled in an organized way [8]. A possible justification could be that increased MCFAs motivated insulin secretion and stimulated anabolic-related processes. Consequently, an increase in de novo fatty acid synthesis may cause a rise in the production of triglycerides [77]. Saeidi et al. [43] reported that quail chicks fed on MCFAsupplemented diet showed decreased serum levels of TC, TG, LDL-C, and increased HDL-C. Zhao et al. [69] reported an optimistic effect of GML supplementation on the lipid profile of laying hens indicated by reducing the the serum TG and TC levels and lowering the abdominal fat.

Concerning the Effect of GML on broiler chickens' immune status, the GML5 diet significantly raised the serum levels of IL10 and IgM. MCFAs bind the orphan receptor GPR84, a signal protein that is mostly expressed in immune cells. GPR84 activated in monocytes and macrophages that boosted lipopolysaccharide production (LPS) and stimulated IL-12 p40, which suggests a mechanism that fixes free fatty acids with immune responses [78]. Even though MCFAs are freely absorbed in the upper intestine, the effect of MCFAs on ILs was studied with colonic cells. MCTs-fed rats showed a rise in IL-6 expression and immunoglobulin A (IgA) secretion after bacterial LPS injection [79]. 
Moreover, MCTs supplementation decreased the LPS-induced expression of proinflammatory chemokines and cytokines and increased anti-inflammatory and immunemodulating cytokine IL-10 in the ileum and Peyer's patches. IgA secretion and modification of cytokine release after LPS injection were proposed to intermediate optimistic effects on animal intestinal health [79]. Dietary MCFAs can resist the microbial activity of Salmonella and Escherichia coli [80,81]. Dietary MCFAs may boost immune function, antibiotic alternatives in poultry nutrition, and decrease the hazard of antimicrobial resistance [39].

\section{Conclusions}

Glycerol monolaurate can supplement broiler chicken diets up to $5 \mathrm{~g} \mathrm{~kg}^{-1}$ in order to enhance the immune status and intestinal histomorphology of birds with no improving effect on the growth performance or amino acid digestibility.

Author Contributions: S.A.A.: Conceptualization, methodology, resources, software, formal analysis, investigation, data curation, visualization, writing —original draft, writing —review and editing. A.A.-N.: Conceptualization, methodology, writing-review and editing. H.S.A.-K: Conceptualization, methodology, writing — review and editing. D.M.M.A.: Conceptualization, methodology, resources, writing - review and editing. D.M.A.f.: Conceptualization, methodology, writing-review and editing. E.M.R.: Conceptualization, methodology, writing-review and editing. W.R.I.A.S.: Conceptualization, methodology, writing - review and editing. M.F.M.F.: Conceptualization, methodology, writing - review and editing. D.E.A.: Conceptualization, methodology, writing—review and editing. A.A.A.A.-W.: Conceptualization, methodology, writing-review and editing. A.E.M.: Conceptualization, methodology, writing - review and editing. All authors have read and agreed to the published version of the manuscript.

Funding: This research received no external funding.

Institutional Review Board Statement: The ethics of the experimental protocol were approved by the Institutional Animal Care and Use Committee of Zagazig University, Egypt (ZUIACUC-2019). All animal experiments were performed following the recommendations described in "The Guide for the Care and Use of Laboratory Animals in scientific investigations."

Informed Consent Statement: Not applicable.

Data Availability Statement: Data sharing not applicable.

Acknowledgments: The authors extend their appreciation to the Faculty of Veterinary Medicine, Zagazig University, Egypt, and the management of the Kuwait Institute for Scientific Research (KISR) for their technical and financial support.

Conflicts of Interest: The authors declared that they have no conflict of interest.

\section{References}

1. Amer, S.A.; Kishawy, A.T.; Osman, A.; Mahrose, K.M.; Hassanine, E.-S.I.; Rehman, Z.U. Influence of dietary graded levels of lycopene on the growth performance, muscle cholesterol level and oxidative status of Japanese quail fed high-fat diet. Anais Acad. Bras. Ciências 2020, 92. [CrossRef]

2. Metwally, A.E.; Abdel-Wareth, A.A.; Saleh, A.A.; Amer, S.A. Are the energy matrix values of the different feed additives in broiler chicken diets could be summed? BMC Vet. Res. 2020, 16, 1-11. [CrossRef] [PubMed]

3. Omar, A.E.; Al-Khalaifah, H.S.; Mohamed, W.A.; Gharib, H.S.; Osman, A.; Al-Gabri, N.A.; Amer, S.A. Effects of Phenolic-Rich Onion (Allium cepa L.) Extract on the Growth Performance, Behavior, Intestinal Histology, Amino Acid Digestibility, Antioxidant Activity, and the Immune Status of Broiler Chickens. Front. Vet. Sci. 2020, 7, 728. [CrossRef] [PubMed]

4. Baltić, Ž.; Marković, R.; Đorđević, V. Nutrition and meat quality. Tehnol. Mesa 2011, 52, 154-159.

5. Šefer, D.; Marković, R.; Nedeljković-Trailović, J.; Petrujkić, B.; Radulović, S.; Grdović, S. The application of biotechnology in animal nutrition. Vet. Glas. 2015, 69, 127-137. [CrossRef]

6. Dierick, N.; Decuypere, J.; Degeyter, I. The combined use of whole Cuphea seeds containing medium chain fatty acids and an exogenous lipase in piglet nutrition. Arch. Anim. Nutr. 2003, 57, 49-63. [CrossRef]

7. Graham, S.A.; Knapp, S.J. Cuphea: A new plant source of medium-chain fatty acids. Crit. Rev. Food Sci. Nutr. 1989, 28, 139-173. [CrossRef]

8. Marten, B.; Pfeuffer, M.; Schrezenmeir, J. Medium-chain triglycerides. Int. Dairy J. 2006, 16, 1374-1382. [CrossRef]

9. Bach, A.C.; Babayan, V.K. Medium-chain triglycerides: An update. Am. J. Clin. Nutr. 1982, 36, 950-962. [CrossRef]

10. Odle, J. New insights into the utilization of medium-chain triglycerides by the neonate: Observations from a piglet model. J. Nutr. 1997, 127, 1061-1067. [CrossRef] 
11. Ramırez, M.; Amate, L.; Gil, A. Absorption and distribution of dietary fatty acids from different sources. Early Hum. Dev. 2001, 65, S95-S101. [CrossRef]

12. Carvajal, O.; Nakayama, M.; Kishi, T.; Sato, M.; Ikeda, I.; Sugano, M.; Imaizumi, K. Effect of medium-chain fatty acid positional distribution in dietary triacylglycerol on lymphatic lipid transport and chylomicron composition in rats. Lipids 2000, 35, 1345-1352. [CrossRef] [PubMed]

13. Bloch, R. Intestinal absorption of medium chain fatty acids. Z. Fur Ernahrungswissenschaft. J. Nutr. Sci. Suppl. 1974, 17, 42-49.

14. Guillot, E.; Lemarchal, P.; Dhorne, T.; Rerat, A. Intestinal absorption of medium chain fatty acids: In vivo studies in pigs devoid of exocrine pancreatic secretion. Br. J. Nutr. 1994, 72, 545-553. [CrossRef] [PubMed]

15. Guillot, E.; Vaugelade, P.; Lemarchali, P.; Rat, A.R. Intestinal absorption and liver uptake of medium-chain fatty acids in non-anaesthetized pigs. Br. J. Nutr. 1993, 69, 431-442. [CrossRef] [PubMed]

16. Greenberger, N.J.; Skillman, T.G. Medium-chain triglycerides. N. Engl. J. Med. 1969, 280, 1045-1058. [CrossRef] [PubMed]

17. Skřivanová, E.; Marounek, M.; Benda, V.; Březina, P. Susceptibility of Escherichia coli, Salmonella sp and Clostridium perfringens to organic acids and monolaurin. Veterinární Med. 2006, 51, 81-88. [CrossRef]

18. Khatibjoo, A.; Mahmoodi, M.; Fattahnia, F.; Akbari-Gharaei, M.; Shokri, A.-N.; Soltani, S. Effects of dietary short-and mediumchain fatty acids on performance, carcass traits, jejunum morphology, and serum parameters of broiler chickens. J. Appl. Anim. Res. 2018, 46, 492-498. [CrossRef]

19. Liu, T.; Li, C.; Li, Y.; Feng, F. Glycerol monolaurate enhances reproductive performance, egg quality and albumen amino acids composition in aged hens with gut microbiota alternation. Agriculture 2020, 10, 250. [CrossRef]

20. Fortuoso, B.F.; Dos Reis, J.H.; Gebert, R.R.; Barreta, M.; Griss, L.G.; Casagrande, R.A.; de Cristo, T.G.; Santiani, F.; Campigotto, G.; Rampazzo, L. Glycerol monolaurate in the diet of broiler chickens replacing conventional antimicrobials: Impact on health, performance and meat quality. Microb. Pathog. 2019, 129, 161-167. [CrossRef]

21. Aviagen, R. Ross Broiler Management Manual. 2009. Available online: http://goldenpoultry.com/wp-content/uploads/2014/0 9/Ross-Broiler-Handbook-2014i-EN.pdf (accessed on 6 November 2014).

22. Brody, S. Bioenergetics and Growth; with Special Reference to the Efficiency Complex in Domestic Animals; Hafner Press: New York, NY, USA, 1974.

23. McDonald, P.; Edwards, R.; Greenhalgh, J. Animal Nutrition, 3rd ed.; Oliver and Boyd: London, UK, 1973 ; pp. 83-84.

24. Amer, S.A.; Naser, M.A.; Abdel-Wareth, A.A.; Saleh, A.A.; Elsayed, S.A.; Abdel fattah, D.M.; Metwally, A.E. Effect of dietary supplementation of alpha-galactosidase on the growth performance, ileal digestibility, intestinal morphology, and biochemical parameters in broiler chickens. BMC Vet. Res. 2020, 16, 1-13. [CrossRef] [PubMed]

25. Li, X.; Ni Gusti Ayu, M.; Zhang, D.; Bryden, W. Apparent ileal amino acid digestibility of Australian sorghum. In Proceedings of the 18th Annual Australian Poultry Science Symposium, Sydney, Austrlia, 20-22 February 2006.

26. Siriwan, P.; Bryden, W.; Mollah, Y.; Annison, E. Measurement of endogenous amino acid losses in poultry. Br. Poult. Sci. 1993, 34, 939-949. [CrossRef] [PubMed]

27. Ravindran, G.; Bryden, W. Tryptophan determination in proteins and feedstuffs by ion exchange chromatography. Food Chem. 2005, 89, 309-314. [CrossRef]

28. Fenton, T.; Fenton, M. An improved procedure for the determination of chromic oxide in feed and feces. Can. J. Anim. Sci. 1979, 59, 631-634. [CrossRef]

29. Allain, C.C.; Poon, L.S.; Chan, C.S.; Richmond, W.; Fu, P.C. Enzymatic determination of total serum cholesterol. Clin. Chem. 1974, 20, 470-475. [CrossRef]

30. McGowan, M.; Artiss, J.D.; Strandbergh, D.R.; Zak, B. A peroxidase-coupled method for the colorimetric determination of serum triglycerides. Clin. Chem. 1983, 29, 538-542. [CrossRef]

31. Vassault, A.; Grafmeyer, D.; Naudin, C.; Dumont, G.; Bailly, M.; Henny, J.; Gerhardt, M.; Georges, P. Protocole de validation de techniques. Ann. Biol. Clin. 1986, 44, 45.

32. Giannenas, I.; Tontis, D.; Tsalie, E.; Chronis, E.; Doukas, D.; Kyriazakis, I. Influence of dietary mushroom Agaricus bisporus on intestinal morphology and microflora composition in broiler chickens. Res. Vet. Sci. 2010, 89, 78-84. [CrossRef]

33. Suvarna, S.K.; Layton, C. The hematoxylins and eosin. In Bancroft's Theory and Practice of Histological Techniques, 7th ed.; Churchill Livingstone: London, UK, 2012; pp. 173-186.

34. Amer, S.A.; Omar, A.E.; Mohamed, W.A.; Gharib, H.S.; El-Eraky, W.A. Impact of Betaine Supplementation on the Growth Performance, Tonic Immobility, and Some Blood Chemistry of Broiler Chickens Fed Normal and Low Energy Diets During Natural Summer Stress. Zagazig Vet. J. 2018, 46, 37-50. [CrossRef]

35. Abd El-Hack, M.; Alagawany, M.; Amer, S.; Arif, M.; Wahdan, K.M.; El-Kholy, M. Effect of dietary supplementation of organic zinc on laying performance, egg quality and some biochemical parameters of laying hens. J. Anim. Physiol. Anim. Nutr. 2018, 102, e542-e549. [CrossRef]

36. Kishawy, A.T.; Amer, S.A.; El-Hack, M.E.A.; Saadeldin, I.M.; Swelum, A.A. The impact of dietary linseed oil and pomegranate peel extract on broiler growth, carcass traits, serum lipid profile, and meat fatty acid, phenol, and flavonoid contents. Asian Australas. J. Anim. Sci. 2019, 32, 1161. [CrossRef] [PubMed]

37. Omar, A.; Amer, S.; Mohamed, W.; Osman, A.; Sitohy, M. Impact of single or co-dietary inclusion of native or methylated soy protein isolate on growth performance, intestinal histology and immune status of broiler chickens. Adv. Anim. Vet. Sci. 2018, 6, 395-405. [CrossRef] 
38. Gouda, A.; Amer, S.A.; Gabr, S.; Tolba, S.A. Effect of dietary supplemental ascorbic acid and folic acid on the growth performance, redox status, and immune status of broiler chickens under heat stress. Trop. Anim. Health Prod. 2020. [CrossRef]

39. Çenesiz, A.; Çiftci, İ. Modulatory effects of medium chain fatty acids in poultry nutrition and health. World's Poult. Sci. J. 2020, 27, 1-15. [CrossRef]

40. De Los Santos, F.S.; Donoghue, A.; Venkitanarayanan, K.; Dirain, M.; Reyes-Herrera, I.; Blore, P.; Donoghue, D. Caprylic acid supplemented in feed reduces enteric Campylobacter jejuni colonization in ten-day-old broiler chickens. Poult. Sci. 2008, 87, 800-804. [CrossRef] [PubMed]

41. Khosravinia, H. Effect of dietary supplementation of medium-chain fatty acids on growth performance and prevalence of carcass defects in broiler chickens raised in different stocking densities. J. Appl. Poult. Res. 2015, 24, 1-9. [CrossRef]

42. Del Alamo, A.G.; De Los Mozos, J.; Van Dam, J.; De Ayala, P. The use of short and medium chain fatty acids as an alternative to antibiotic growth promoters in broilers infected with malabsorption syndrome. In Proceedings of the 16th European Symposium on Poultry Nutrition, Strasbourg, France, 26-30 August 2007; pp. 317-320.

43. Saeidi, E.; Shokrollahi, B.; Karimi, K.; Amiri-Andi, M. Effects of medium-chain fatty acids on performance, carcass characteristics, blood biochemical parameters and immune response in Japanese quail. Br. Poult. Sci. 2016, 57, 358-363. [CrossRef]

44. Tellez, G.; Higgins, S.; Donoghue, A.; Hargis, B. Digestive physiology and the role of microorganisms. J. Appl. Poult. Res. 2006, 15, 136-144. [CrossRef]

45. Mountzouris, K.; Tsitrsikos, P.; Palamidi, I.; Arvaniti, A.; Mohnl, M.; Schatzmayr, G.; Fegeros, K. Effects of probiotic inclusion levels in broiler nutrition on growth performance, nutrient digestibility, plasma immunoglobulins, and cecal microflora composition. Poult. Sci. 2010, 89, 58-67. [CrossRef]

46. Hayat, T.; Sultan, A.; Khan, R.U.; Khan, S.; Ullah, R.; Aziz, T. Impact of organic acid on some liver and kidney function tests in Japanese quails, Coturnix coturnix japonica. Pak. J. Zool. 2014, 46, 1179-1182.

47. Gunal, M.; Yayli, G.; Kaya, O.; Karahan, N.; Sulak, O. The effects of antibiotic growth promoter, probiotic or organic acid supplementation on performance, intestinal microflora and tissue of broilers. Int. J. Poult. Sci. 2006, 5, 149-155.

48. Vieira, S.L.; Oyarzabal, O.; Freitas, D.; Berres, J.; Pena, J.; Torres, C.; Coneglian, J. Performance of broilers fed diets supplemented with sanguinarine-like alkaloids and organic acids. J. Appl. Poult. Res. 2008, 17, 128-133. [CrossRef]

49. Abdollahi, M.; Zaefarian, F.; Ravindran, V. Feed intake response of broilers: Impact of feed processing. Anim. Feed Sci. Technol. 2018, 237, 154-165. [CrossRef]

50. Hejdysz, M.; Wiąz, M.; Zefiak, D.; Rutkowski, A. Effect of medium chain fatty acids (MCFA) on growth performance and nutrient utilization in broiler chickens. Rocz. Nauk. Pol. Tow. Zootech. 2012, 8, 9-17.

51. Liu, T.; Li, C.; Zhong, H.; Feng, F. Dietary medium-chain $\alpha$-monoglycerides increase BW, feed intake, and carcass yield in broilers with muscle composition alteration. Poult. Sci. 2020, 100, 186-195. [CrossRef] [PubMed]

52. Lipiński, K.; Mazur, M.; Makowski, Z.; Makowska, A.; Antoszkiewicz, Z.; Kaliniewicz, J. The effectiveness of the preparation medium-chain fatty acids (MCFA) and a herbal product on the growth performance of turkeys. Pol. J. Nat. Sci. 2016, $31,47-57$.

53. Devi, S.M.; Kim, I. Effect of medium chain fatty acids (MCFA) and probiotic (Enterococcus faecium) supplementation on the growth performance, digestibility and blood profiles in weanling pigs. Vet. Med. 2014, 59, 527-535. [CrossRef]

54. Mabayo, R.; Furuse, M.; Kita, K.; Okumura, J. Improvement of dietary protein utilisation in chicks by medium chain triglyceride. Br. Poult. Sci. 1993, 34, 121-130. [CrossRef]

55. Allee, G.; Romsos, D.; Leveille, G.; Baker, D. Metabolic consequences of dietary medium-chain triglycerides in the pig. Proc. Soc. Exp. Biol. Med. 1972, 139, 422-427. [CrossRef]

56. Baltić, B.; Ćirić, J.; Šefer, D.; Radovanović, A.; Đorđević, J.; Glišić, M.; Bošković, M.; Baltić, M.; Đorđević, V.; Marković, R. Effect of dietary supplementation with medium chain fatty acids on growth performance, intestinal histomorphology, lipid profile and intestinal microflora of broiler chickens. S. Afr. J. Anim. Sci. 2018, 48, 885-896. [CrossRef]

57. Decuypere, J.; Dierick, N. The combined use of triacylglycerols containing medium-chain fatty acids and exogenous lipolytic enzymes as an alternative to in-feed antibiotics in piglets: Concept, possibilities and limitations. An overview. Nutr. Res. Rev. 2003, 16, 193-210. [CrossRef] [PubMed]

58. Takase, S.; Goda, T. Effects of medium-chain triglycerides on brush border membrane-bound enzyme activity in rat small intestine. J. Nutr. 1990, 120, 969-976. [CrossRef] [PubMed]

59. Garcia, V.; Catala-Gregori, P.; Hernandez, F.; Megias, M.; Madrid, J. Effect of formic acid and plant extracts on growth, nutrient digestibility, intestine mucosa morphology, and meat yield of broilers. J. Appl. Poult. Res. 2007, 16, 555-562. [CrossRef]

60. Kum, S.; Eren, U.; Onol, A.; Sandikci, M. Effects of dietary organic acid supplementation on the intestinal mucosa in broilers. Rev. Med. Vet 2010, 10, 463-468.

61. Rodríguez-Lecompte, J.; Yitbarek, A.; Brady, J.; Sharif, S.; Cavanagh, M.; Crow, G.; Guenter, W.; House, J.; Camelo-Jaimes, G. The Effect of microbial-nutrient interaction on the immune system of young chicks after early probiotic and organic acid administration. J. Anim. Sci. 2012, 90, 2246-2254. [CrossRef]

62. Sultan, A.; Ullah, T.; Khan, S.; Khan, R.U. Effect of organic acid supplementation on the performance and ileal microflora of broiler during finishing period. Pak. J. Zool. 2015, 47, 635-639.

63. Abudabos, A.M.; Alyemni, A.H.; Dafalla, Y.M.; Khan, R.U. Effect of organic acid blend and Bacillus subtilis alone or in combination on growth traits, blood biochemical and antioxidant status in broilers exposed to Salmonella typhimurium challenge during the starter phase. J. Appl. Anim. Res. 2017, 45, 538-542. [CrossRef] 
64. Leeson, S.; Namkung, H.; Antongiovanni, M.; Lee, E. Effect of butyric acid on the performance and carcass yield of broiler chickens. Poult. Sci. 2005, 84, 1418-1422. [CrossRef]

65. Panda, A.; Rao, S.; Raju, M.; Sunder, G.S. Effect of butyric acid on performance, gastrointestinal tract health and carcass characteristics in broiler chickens. Asian Australas. J. Anim. Sci. 2009, 22, 1026-1031. [CrossRef]

66. Adil, S.; Banday, T.; Bhat, G.A.; Mir, M.S.; Rehman, M. Effect of dietary supplementation of organic acids on performance, intestinal histomorphology, and serum biochemistry of broiler chicken. Vet. Med. Int. 2010, 2010. [CrossRef]

67. Awad, W.; Ghareeb, K.; Abdel-Raheem, S.; Böhm, J. Effects of dietary inclusion of probiotic and synbiotic on growth performance, organ weights, and intestinal histomorphology of broiler chickens. Poult. Sci. 2009, 88, 49-56. [CrossRef] [PubMed]

68. Van der Aar, P.; Molist, F.v.; Van Der Klis, J. The central role of intestinal health on the Effect of feed additives on feed intake in swine and poultry. Anim. Feed Sci. Technol. 2017, 233, 64-75. [CrossRef]

69. Zhao, M.-j.; Cai, H.-y.; Liu, M.-y.; Deng, L.-1.; Li, Y.; Zhang, H.; Feng, F.-q. Effects of dietary glycerol monolaurate on productive performance, egg quality, serum biochemical indices, and intestinal morphology of laying hens. J. Zhejiang Univ. Sci. B 2019, 20, 877. [CrossRef]

70. Liu, T.; Tang, J.; Feng, F. Glycerol monolaurate improves performance, intestinal development, and muscle amino acids in yellow-feathered broilers via manipulating gut microbiota. Appl. Micro. Biotech. 2020, 104, 10279-10291. [CrossRef]

71. Pan, D.; Yu, Z. Intestinal microbiome of poultry and its interaction with host and diet. Gut Microbes 2014, 5, 108-119. [CrossRef]

72. Yu, M.; Mu, C.; Zhang, C.; Yang, Y.; Su, Y.; Zhu, W. Marked response in microbial community and metabolism in the ileum and cecum of suckling piglets after early antibiotics exposure. Front. Microbiol. 2018, 9, 1166. [CrossRef]

73. Mo, Q.; Fu, A.; Deng, L.; Zhao, M.; Li, Y.; Zhang, H.; Feng, F. High-dose glycerol monolaurate up-regulated beneficial indigenous microbiota without inducing metabolic dysfunction and systemic inflammation: New insights into its antimicrobial potential. Nutrients 2019, 11, 1981. [CrossRef] [PubMed]

74. Zhang, X.; Zhang, Y.; Liu, Y.; Wang, J.; Xu, Q.; Yu, X.; Yang, X.; Liu, Z.; Xue, C. Medium-chain triglycerides promote macrophage reverse cholesterol transport and improve atherosclerosis in ApoE-deficient mice fed a high-fat diet. Nutr. Res. 2016, 36, 964-973. [CrossRef] [PubMed]

75. Zhou, S.; Wang, Y.; Jacoby, J.r.J.; Jiang, Y.; Zhang, Y.; Yu, L.L. Effects of medium-and long-chain triacylglycerols on lipid metabolism and gut microbiota composition in C57BL/6J mice. J. Agric. Food Chem. 2017, 65, 6599-6607. [CrossRef] [PubMed]

76. Shokrollahi, B.; Yavari, Z.; Kordestani, A. Effects of dietary medium-chain fatty acids on performance, carcass characteristics, and some serum parameters of broiler chickens. Br. Poult. Sci. 2014, 55, 662-667. [CrossRef] [PubMed]

77. Hill, J.; Peters, J.; Swift, L.; Yang, D.; Sharp, T.; Abumrad, N.; Greene, H. Changes in blood lipids during six days of overfeeding with medium or long chain triglycerides. J. Lipid Res. 1990, 31, 407-416. [PubMed]

78. Wang, J.; Wu, X.; Simonavicius, N.; Tian, H.; Ling, L. Medium-chain fatty acids as ligands for orphan G protein-coupled receptor GPR84. J. Biol. Chem. 2006, 281, 34457-34464. [CrossRef] [PubMed]

79. Kono, H.; Fujii, H.; Asakawa, M.; Maki, A.; Amemiya, H.; Hirai, Y.; Matsuda, M.; Yamamoto, M. Medium-chain triglycerides enhance secretory IgA expression in rat intestine after administration of endotoxin. Am. J. Physiol. Gastrointest. Liver Physiol. 2004, 286, G1081-G1089. [CrossRef] [PubMed]

80. Dierick, N.; Decuypere, J.; Molly, K.; Van Beek, E.; Vanderbeke, E. The combined use of triacylglycerols (TAGs) containing medium chain fatty acids (MCFAs) and exogenous lipolytic enzymes as an alternative to nutritional antibiotics in piglet nutrition: II. In vivo release of MCFAs in gastric cannulated and slaughtered piglets by endogenous and exogenous lipases; effects on the luminal gut flora and growth performance. Livest. Prod. Sci. 2002, 76, 1-16.

81. Rossi, R.; Pastorelli, G.; Cannata, S.; Corino, C. Recent advances in the use of fatty acids as supplements in pig diets: A review. Anim. Feed Sci. Technol. 2010, 162, 1-11. [CrossRef] 